\title{
Durga Puja Pandals of Kolkata 2016: The Heritage and the Design
}

\author{
Tripti Singh
}

\begin{abstract}
Durga Puja [1] also known as Sharadotsav or Durgotsava is an annual festival of West Bengal, India, where artists, designers and architects use innovative themes to decorate unique pandals to impress the visitors each year. It involves planning and tedious hard work to give it virtual form. It was interesting that Kolkata (formerly Calcutta) is the capital of India's West Bengal state has an area of $185 \mathbf{~ k m}^{2}$, more than 4500 pandals [2] were erected in that area during the five - day of Durga Puja was from October 7 until October 11, 2016.

Each year there are unique themes which comprise art and design techniques at the single place, time and event. Pandals are distinctive from each other, also they deliver a meaningful message to the society. Those pandals are not only a matter of rituals, devotion and aesthetics, but it is a way to realise the ideologies that are dominating current society.

It needed to physically capture the event and document the designs, to understand it with soul, spirit and body. The author connected, visited, studied, captured and documented as a researcher of new media art and faculty of traditional, digital and modern installations. The author finds it was the biggest event which can tell so much about current practices, that no other event in the country can knowledge the variety in the context of art and design techniques then this one of a kind held in the country.

This paper will explain and acknowledge the art, and design techniques used in some of Durga Puja pandals where the author visited during 7th -11th October 2016 in Kolkata.
\end{abstract}

Index Terms - Durgapuja, pandals, kolkata, calcutta, design, multicultural, surrealistic.

\section{INTRODUCTION}

Durga Puja is celebrated in Bengal [3] from 17th-18th century by Bengali [4] Zamindars [5] inform of annual Durga Puja in their family rajbaris (palaces). In early 20th century because of increasing large-scale celebrations which needed lots of money hence it became the Sarbojanin or community celebration of the festival which is sponsored and organised by the neighbourhood.

In the 21 st century the family Durga Puja is instinct, but very few zamindar and merchant families continue to celebrate pujas in their palaces. Now Kolkata's popular Durga Puja celebration is group, community or neighbourhood activity. It is an occasion of experimentations by designer, artisans and craftsman in Kolkata both in the format of the idols [6] and decoration of the pandal (canopied bamboo structure) in which the idols are housed.

Manuscript received October 12, 2017; revised December 25, 2017.

Tripti Singh is with the Indian Institute of Information Technology, India (e-mail: ts@iiitdmj.ac.in).
There is one theme all over which is to worship mother nature, through modern traditions have sub-themes. These sub-themes which are different in each Durga Puja pandals throughout the region. They display theme based artistically depicted sculptures of an idol of Maa Durga [7]. Puja organisers put a lot of time, thinking and a lot of means on these themed pandals. These pandals are works of art in their own right. The creativity stun, attract attention and praise of viewers. The artistic achievements are to attract the visitor. There are also token of appreciation through prizes of a different category to be won by the designer.

\section{BRIEF DESCRIPTION OF MYTHOLOGY}

It is believed that the Goddess Durga's victory over the demon Mahishasur [8] and also Lord Rama [9] had worshipped the goddess Durga to seek divine blessings before undertaking the battle against Ravana [10] in Ramayana.

\section{A. Durga Puja Celebration Days}

Durga Puja in Kolkata a festival which is a religious event, celebrated according to Bengali festival calendar [11], celebrated in autumn. It is a ten-day festival, which starts from Mahalaya [12], the inaugural day of the event. Mahalaya is celebrated by Agomoni (songs of welcome). Festivities start five days later with the observance of Shashti [13], Shaptami [14], Ashtami [15], and Nabami [16]. On the tenth day, or Bijoya Dashami [17], the goddess is borne away to the sounds of the dhak, or traditional drum for immersion in nearby rivers or water bodies.

\section{B. Durga Puja Calendar 2016}

Day as per Occasion Date:

Bodhon or Mahalaya, First Day, 1st October 2015

Panchmi, Fifth Day, 6th October 2016

Shashthi, Sixth day, 7th October 2016

Saptami, SeventhDay, 8th October 2016

Ashtami, Eight biggest day, 9th October 2016

Nabami/Dashami, Ninth \& Tenth Day, 10th-11th October 2016

\section{Durga Puja}

The puja mandap or the main altar is a platform inside a bamboo structure called a pandal. Inside the pandal, rituals are performed by the priests in front of the deities. Offerings of fruits, flowers, sweetmeats, incense and sandalwood are placed in front of the deities while the congregation in the pandal repeat the mantras [18].

\section{Durga Puja Pandals and Theme}

The whole festival is based on the 'Neighbourhood'. Every neighbourhood builds it's 'pandal'. The 
neighbourhood's uniqueness is articulated in the form of the symbolism of the pandal. The temporary pandal provides some moments of relief from the continuous engagement of people's daily fight for survival, it gives the opportunity to live a momentary phase for dreaming and imagining. This is an occasion to discover thoughts, ideas and community solidarity. As more than thousands of neighbourhoods engage in building their pandals, therefore, the entire city engaged in the frenzy of the festival and it transforms the city into a surreal world. When a traverses through these pandals, a distinctive landscape of the city emerges which unravels the dynamics of the various neighbourhoods. The interactions arise within and amongst their ethos, dreams and aspirations.

The act of building the pandal is an important link to the neighbourhood's life, it acts as a medium to stage, shape and transforms public opinion by stimulating confirmation, dialogue and debate. People of the neighbourhood involve with these stages, irrespective of gender, age, economic class, occupation, caste and religion gather to dream and debate.

Each year they have to face some questions e.g. "What will our theme of pandal into this year? How do we design the Pandal in the limited space? What will be portrayed to the world through the Pandal? How much means will be required? External resources? Professional assistance to design and create the pandal? And closely followed by, "How to make our pandal best in aesthetically this year? What will be the message that our neighbouring pandal is trying to convey?"

\section{BUILDING MATERIALS OF PANDAL}

The Pandal-in earlier times the pandal was the temporary abode, they were made of simple bamboo scaffolding with metres of cloth draped around it. Now-a-days the pandals are built in all conceivable forms and complex structure which replicas of famous temples, parliament houses, mansions, forts, etc. The materials used in the construction of these pandals are no longer the simple and cost effective but complicated and very costly.

Pandals created using lots of materials some are ecofriendly some are not. Some are waste material and some are specifically created, some materials are fragile and elegant, whereas some are strong. Some materials locally found and in some pandals these materials are imported. Some of this material are e.g. plastic, papers, soil, plaster-ofparis.

Designers decorate pandals in the most astonishing ways as they can, using different materials e.g. terracotta, old LP records, biscuits, coke bottles, matchboxes etc to name few.

The theme can be sea-shells, ancient temples, forts, ships, igloos and even the White House and some theme can be simply motivation, thoughts or ideas which can be in from fantasies, political conflicts, flaccid socio-economic condition and parenthood.

Pandal-making-is an extremely tactile method of building, it has a connection between materials and the craftsman's method of constructing. The soil in this region is suitable for bamboo to grow in abundance and also it is good for wattle and daub construction. Over centuries craftsmen are using these techniques while working with bamboo and mud to build houses in this region. Most houses in villages of Bengal are built in this technique. Other locally sourced materials are straw, jute, rice-husk, paper and timber are used in pandals. These are most natural and ecological materials which can be used in construction. The festival ensures that most materials used can easily be dismantled and reused. A bamboo-framework attains form with crafted elements and finishes. Steel is also used, though sparingly, in some large pandals to make a framework. In recent times, some pandals also use disposed or waste products for construction. The rooted tradition, the craftsmen engage themselves in innovative ways to combine regional craft with technology and new tools.

Two months prior to Durga Puja, craftsmen start to prepare to build the pandal. It started with reverberates with energy, discussions and joyful anticipation of the unseen world that it is about to transform into.

Bamboo, clay, timber-posts, plaster and hay get collected at the corner of a street. A designer with her/his team of craftsmen takes responsibility to build a unique pandal s/he will have a conversation with neighbourhood people and then sets out the design and build the Pandal. The streetscape transforms into his/her studio. Tools mould materials; dreams become reality; the Pandal emerges gradually.

The Idol-The makeshift structures idols of the goddess are adorned with meticulous artwork and stylistic themes made with local craft materials such as shola or pith, woven brocades, coloured jute, clay and terracotta [20] ornamentation and imitation jewellery.

The festival has become the means of livelihood for innumerable local craftsmen. For example, an entire neighbourhood, 'Kumartuli' craftsmen are knowledgebearers of the regional sculpting method of straw-bamboo armatures and clay, characteristically used for sculpting Durga idols.

The rituals of deities in which material are used as rice, dry flour, flower petals, turmeric (haldi), Vermillion (Sindoor) [20] and coloured sand.

\section{A SURREALISTIC WORLD -DURGA PUJA PANDAL IN KOLKATA}

An overcrowded street and pandals with people, rickshaws [21] and taxis in hustled transit lead to one to another pandal visits.

The festival finally arrives. The neighbourhood transforms into a surrealistic world, with time and history indiscriminately collapse and an entirely new installation is born in form of pandal which was never seen before and will be never seen afterwards. The pandal becomes a public domain. It is open to being experienced, discussed and interpreted throughout day and night. Then it became no longer a single viewpoint or experience but the merging of collective experiences of people. It sensitises them and that it evokes their feelings.

At the far end of the pandal, a towering form, magnificently rising from the corner of a neighbourhood, magnetically draws the viewers towards it. It welcomes all, to make a relation to it, to solve the threshold of a large 
symbolic gateway, it act as a trellis of creeper-like sculptural forms and to find sacred precinct.

The pandal seems to be an enclosure of intricately crafted, makeup of mud-bamboo walls on either side of a ramp, which holds the sacred space. It feels like a dramatic journey of ascent conditions in which the mind to a heightened state of rapture. The viewer feels the constant reversal of uniqueness from one pandal to another and from front to forth. The use of materials, colours, textures and shadows of decorated pandals make people respond childlike. Every detail, curvature and texture show the excellence of design and craftsmanship with the materials. The play of light and shadow reverberating with ritual-sounds make surfaces progressively reveal the hidden pleasure of the pandal.

TABLE I: SOME OF DURGa PUJA PANDALS AND THERE DECORATION

\begin{tabular}{|c|c|c|c|c|}
\hline S.No & Name & Pandal & Idol & Details \\
\hline 1 & $\begin{array}{l}\text { Chakraberia } \\
\text { Sarbojanin } \\
\text { Durgotsab } \\
\text { Committee, } \\
\text { Triangular } \\
\text { Park }\end{array}$ & & & \\
\hline 2 & $\begin{array}{l}\text { Ekdalia } \\
\text { Evergreen }\end{array}$ & & & \\
\hline 3 & $\begin{array}{l}\text { Suruchi } \\
\text { Sangha }\end{array}$ & & & \\
\hline 4 & $\begin{array}{l}\text { Tridhara } \\
\text { Sammilani }\end{array}$ & & & \\
\hline 5 & $\begin{array}{l}\text { Suhrid } \\
\text { Sangha, } \\
\text { Rashbehari }\end{array}$ & & & \\
\hline 6 & $\begin{array}{l}\text { Haridevpur } \\
\text { Ajeyo } \\
\text { Sanghati }\end{array}$ & & & \\
\hline 7 & $\begin{array}{l}95 \text { Palli - } \\
\text { Jodhpur Park }\end{array}$ & & & \\
\hline 8 & Barisha Club & & & \\
\hline 9 & $\begin{array}{l}\text { Behala } \\
\text { Natun Dal }\end{array}$ & & & \\
\hline
\end{tabular}

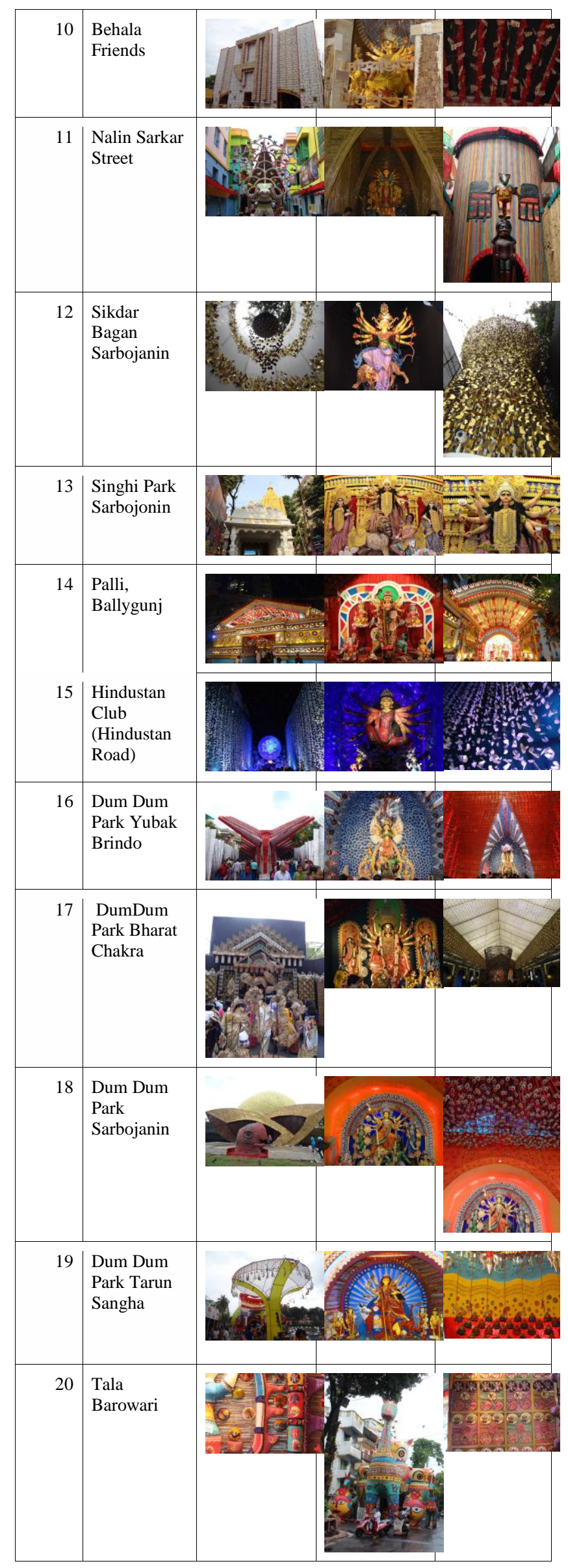




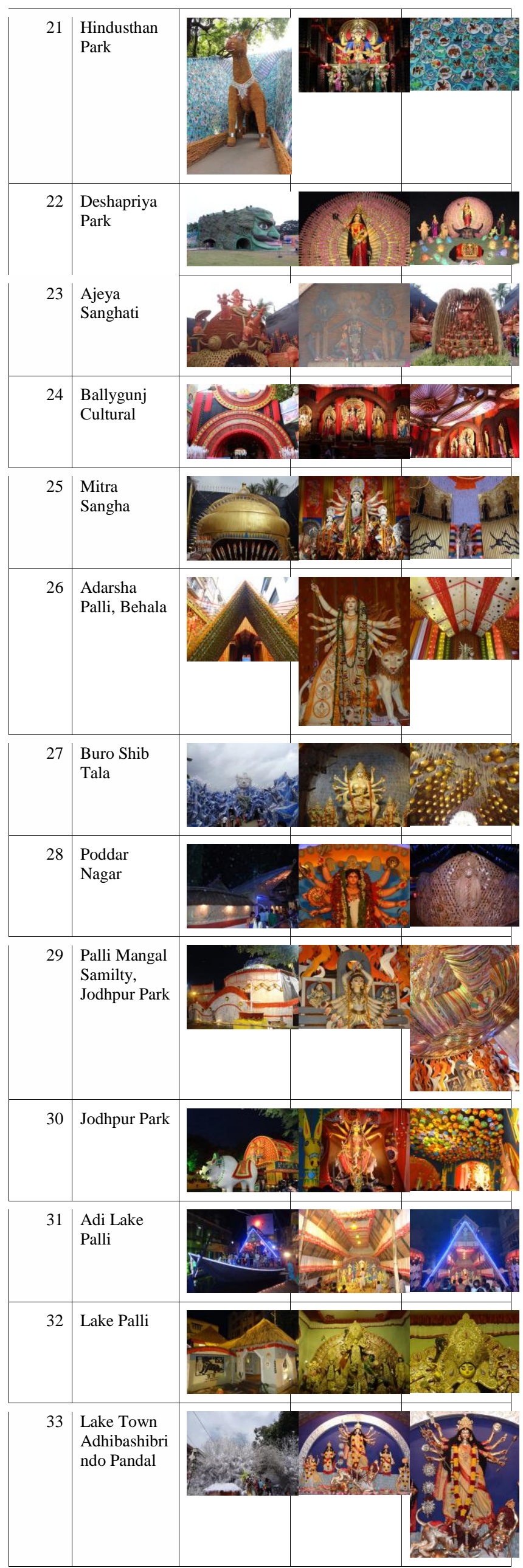

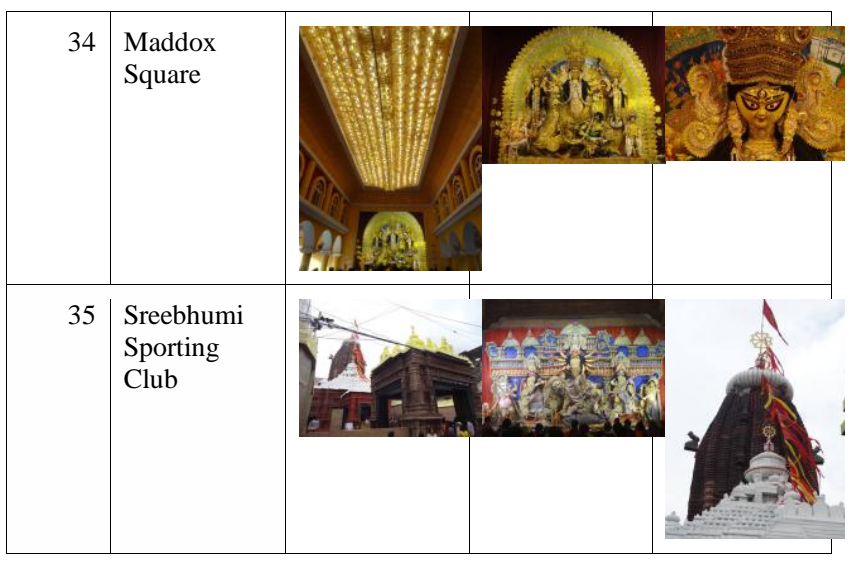

\section{LAST DAY}

On the last day of the festival, the Goddess idol is immersed into flowing water of the sea. The festival concludes, the pandal dismantled and space reverts back to the routine life. This festival keeps traditions alive through the annual rituals of constructing, participating, viewing and debating.

\section{CONCLUSION}

The entire Kolkata city welcomes people from around the world with open arms and hearts filled with incomprehensible emotions of togetherness. The Kolkata streets from the northern points of Tala and Bagbazar to the swanky southern pandals of Naktala and Behala witness waves of darshanarthis or 'pandal-hopping pilgrims' dressed in the best possible way, visiting and mesmerising by the beauty of design, hard work and craftsmanship in the form of pandals.

However, the appearance of the puja (worship) may feel like religious activities which are filled with rituals when it comes to following the tradition. But apart from the religious rituals, Durga Puja in Kolkata has its own trademark features that make it all the more exclusive and distinct from any other celebration in the world.

It is felt that commercialisation of Durga Puja in the last quarter of the 20th century have become a major environmental concern as people want bigger and brighter sculptures. And the pandals and other the sculptures are often made from hazardous materials like cement, plastic, plaster of Paris, and toxic paints.

Through researcher feels there is a great need to document Durga Puja pandals each year as, the process, belief and socio-economic status is changing rapidly. It has been difficult to capture all more than 4000 Durga Puja pandals in Kolkata, as it needs a full team to capture the event. But researcher tried her level best to capture and documented as many as pandals possible in this paper. Some of the puja pandals are not included in this paper as it needs more space.

This paper can be a base of further research topics such as design, colours, theme and motifs used in Durga Puja pandals etc. Stories and experiences from designers, artist and craftsman of Creator of Durga Puja pandals will be valuable assets for research in the field of Art, Design and 
Craft.

\section{REFERENCES}

[1] D. Puja, D. Puja is an annual Hindu festival in South Asia that celebrates worship of the Hindu goddess Durga. It refers to all the six days observed as Mahalaya, Shashthi, Maha Saptami, Maha Ashtami, Maha Navami and Vijayadashami, C. J. Fuller, "The camphor flame: Popular Hinduism and society in India," Princeton University Press, $p$ 83, 2010.

[2] P. A. Pandal, (mandat in Burmese, from Pali mandapa) is a fabricated structure, either temporary or permanent, that is used in a religious event that gathers people together, such as a wedding or festival. In Hinduism, a pandal is a temporary structure set up to venerate the god Ganesha during Ganesh Chaturthi or the goddess Durga during Durga Puja, known as the puja pandal, K. Z. Htun and Y. Htun, "Constructing a pandal for festival fun," Myanmar Times, Retrieved 13 May 2012.

[3] Bengal is a region in Asia which is located in the eastern part of the Indian subcontinent at the apex of the Bay of Bengal, E. Lethbridge, "An easy introduction to the history and geography of bengal: For the junior classes in schools," Thacker, p. 5, January 2017.

[4] Bengali, The Bengalis are a major Indo-Aryan ethnic group, They are native to the region of Bengal in South Asia, which is presentlydivided between Bangladesh and the Indian state of West Bengal. They speak the Bengali language, R. Ray, "History of the Bengali people," Orient BlackSwan, p. 656, 1994.

[5] Zamindars, A zamindar in the Indian subcontinent was an aristocrat. The term means "land owner" in Persian.

[6] M. Lane and R. John, "Land and local kingship in eighteenth-century Bengal," Cambridge University Press, p. 223, 2002, Idols, An idol is an image or other material object representing a deity to which religious worship is addressed or any person or thing regarded with admiration, adoration, or devotion.

[7] J. Cort, Jains in the World, Oxford University Press, ISBN 978-0-19979664-9, pages 80-85, 2011, M. Durga, is the form of mother goddess in Shaktism, M. D. June, "Offering flowers, feeding skulls: Popular goddess worship in west Bengal," Oxford University Press, p. 214, 2004

[8] Mahishasur, According to Hindu mythology, Mahishasura was a combination of both an Asura and a Mahisha (Water buffalo) with a trident. He intended to annihilate all the Devas since they were the arch-enemies of Asuras, Mahishasur. http: www.maavaishnodevi.org. [Online]. Available: /www.maavaishnodevi.org/

[9] Lord Rama, or Srī Rāmachandra is the seventh avatar of the Hindu God Vishnu. He is the central figure of the Hindu epic Ramayana, which is the principal narration of the events connected to his incarnation on Earth, his ideals and his greatness, E. C. D. Jr, "Doctrine and practice among the vaisnavas of Bengal," History of Religions, vol. 3, no. 1, pp. 106-127, 1963.

[10] Ravana, is the primary antagonist in the Hindu mythological tale as told in the ancient Hindu epic Ramayana where he is depicted as Rakshasa (demon) king of Lanka, M. Vettam, "Puranic encyclopaedia: A comprehensive dictionary with special reference to the epic and Puranic literature,” Delhi: Motilal Banarsidass, p. 354, 1995.

[11] Bengali festival calendar, The Bengali Calendar or Bangla Calendar is a solar calendar used in the region of Bengal. A revised version of the calendar is the national and official calendar in Bangladesh and an earlier version of the calendar is followed in the Indian states of West Bengal, Tripura and Assam, K. Chakrabarti and S. Chakrabarti, "Calendar," Historical Dictionary of the Bengalis, Scarecrow Press, pp. 114-5, 2013.

[12] Mahalaya Pitri Paksha is a 16-lunar day period in Hindu calendar when Hindus pay homage to their ancestor (Pitrs), especially through food offerings. In southern and western India, it falls in the 2nd paksha (forthnight)Hindu lunar month of Bhadrapada (September)and follows the forthnight immediately after the Ganesh festival. It begins on the Padyami (first day of the forthnight) ending with the new moon day known as Mahalaya, S. Usha, "Mahalaya," Festivals In Indian Society, pp. 72-73, 2008 .
[13] Shashti also referred to as Chhath is the sixth day or tithi of a Paksha or fourteen-day phase of the moon. The sixth tithi, especially in the waxing period (shuklapaksha).

[14] Shaptami Lord Vishnu in his form as Surya is usually worshiped on this day. Usually, pthami (seventh day). It also involves doing a puja with the ritual 'Naivedyam', flowers and fruits.

[15] Ashtami, Eight day, Ernst Wilhelm, Classical Muhurta, Ashtami, Kala Occult Publishers, 2012.

[16] Nabami (the Great Navratri) is part of Navaratri celebrations. In simple terms, it means "Worship of Implements."

[17] Bijoya Dashami takes place on Mahalaya, the day the Goddess was conceived, and ends on Bijaya Dashami (the victorious tenth day), the day the Goddess finally kills the demon, Bangiya Sabarna Katha Kalishetra Kalikatah by Bhabani Roy Choudhury, Manna Publication.

[18] Mantras, A "Mantra" is a sacred utterance, a numinous sound, a syllable, word or phonemes, or group of words in Sanskrit, J. Gonda, The Indian Mantra, Oriens, vol. 16, pp. 244-297, 1963.

[19] Terracotta, terra cotta or terra-cotta, Italian: "baked earth", from the Latin terra cocta), a type of earthenware, is a clay-based unglazed or glazed ceramic, where the fired body is porous, M. P. Philip and Yankah, African Folklore: An Encyclopedia, 2004

[20] Sindoor, or sindooram is a traditional vermilion red or orange-red colored cosmetic powder from India, usually worn by married women along the parting of their hair, S. J. Tharu and K. Lalita, "Women writing in India: The twentieth century, Feminist Press, 1993.

[21] Rickshaws, A pulled rickshaw (or ricksha) is a mode of humanpowered transport by which a runner draws a two-wheeled cart which seats one or two people.

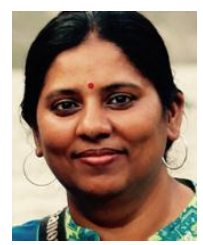

Tripti Singh is an assistant professor, Design Discipline, IIITDM Jabalpur, M.P. India. She previously worked in India's premier Institutes e.g. IIT Mandi as Media Design Fellow and for IIT Kanpur as Scientist. She specialized in Communication Design, 6+ years career with extensive experience in education in Designing, Fashion Textiles, Multimedia, Web design and Print Design. 14 years' experience as Digital Medium Artist.

Extended expertise Designing in Info-graphics, Data \& information collection in multimedia content, i.e. Photography, Animation, Audio Visual, Visualization, Site Design, Mobile page graphics, Logo Design, Animation, Painting and Sketching (Tablet).

Her research interest are:

1. To document festival of India. The documentation will be based on the places, uniqueness of celebration, connecting people as mass activities, and the changes in ritual and celebration of the past. This documentation is based on collecting images and information from different resources.

2. To develop curriculum and lab facilities for New media arts and Digital arts to meet different requirements of an institute. I feel it has lots of possibilities for all, such as scientists, researchers, engineering students more over for the institute as a whole. It is felt that visual documentation is required for all research areas and exposure of the institute. Why arts? well, I feel art is required to encourage students to experiment more those tools which are also used in developing serious visuals. We also need facilities to develop studios or lab for virtual classrooms is today's need. Both sophisticated and mobile phones can be used for fulfilling different requirements for developing multimedia contents.

3. Visual content repositories (Web Site development) on awareness based on topics such as women and children issues, animal human conflict and old age issues etc. 